\title{
SEASIONAL COLD ACCUMULATOR WITH FREE-COOLING IN AIR CONDITIONING SYSTEMS
}

\begin{abstract}
One of the ways to reduce the consumption of traditional energy sources is the use of seasonal cold accumulator that takes advantage of the geographical location in the country and allows, during the winter season, from November to March, accumulate cold because of lower ambient temperature in these months. This leads to saving a significant amount of electricity and reduce operating refrigerant, which is dangerous for the environment. This paper presents a method for determining the size of cold storage with charging devices as chiller and drycooler. The approximate costs of device operation including the time of framework of these components on costs of device operation including the time of framework of these components have been obtained. Design seasonal cold accumulator allows to conclude that this solution has a number of economic and ecological advantages. Due to the seasonal tank design the saves on chiller, which under normal circumstances would have been selected for the highest hourly energy demand, which means that the device should be several times larger than the device that was used in the project. By selecting a small chiller the environment from hazardous refrigerants is protected, which are chlorofluorocarbons, specifically in the case of refrigerant called R- 410A.
\end{abstract}

Keywords: free-cooling, cold accumulator, air-conditioning, seasional storage

\section{Indices}

$\theta_{e}$ - average soil temperature on $3 \mathrm{~m}$ under the ground $\left[{ }^{\circ} \mathrm{C}\right]$,

$t_{m}$ - number of hours in month [h],

$\theta_{z p}$ - temperature in tank on the beginning of month $\left[{ }^{\circ} \mathrm{C}\right]$,

1 Autor do korespondencji/corresponding author: Sławomir Rabczak, Politechnika Rzeszowska, al. Powstańców Warszawy 12, 35-959 Rzeszów, tel. 17 8651699, rabczak@prz.edu.pl

${ }^{2}$ Danuta Proszak-Miąsik, Politechnika Rzeszowska, al. Powstańców Warszawy 12, 35-959 Rzeszów, tel. 17 8651699, dproszak@ prz.edu.pl

${ }^{3}$ Krzysztof Nowak, Politechnika Rzeszowska, al. Powstańców Warszawy 12, 35-959 Rzeszów, tel. 17 8651699, krzynow@ prz.edu.pl 
$Q_{C, n d}-$ cooling demand [kWh/year],

$Q_{t r} \quad-$ monthly heat losses of tank accumulator $[\mathrm{kWh} / \mathrm{m}]$,

$t_{C} \quad$ - discharge time $[\mathrm{h}]$,

$Q_{x} \quad$ - additional cooling energy for service and maintain (October) $[\mathrm{kWh} / \mathrm{m}]$,

$Q_{k} \quad$ - cooling demand including dry-cooler $[\mathrm{kWh} / \mathrm{m}]$,

$Q_{k x} \quad$ - overall monthly cooling demand $[\mathrm{kWh} / \mathrm{m}]$,

$\theta_{z k} \quad$ - temperature on the end of month in tank $\left[{ }^{\circ} \mathrm{C}\right]$,

$\theta_{s r} \quad$ - average temperature in accumulation tank $\left[{ }^{\circ} \mathrm{C}\right]$,

$\theta_{p} \quad$ - dry-cooler temperature operation $\left[{ }^{\circ} \mathrm{C}\right]$,

$t_{m p}$ - number of hours in month that satisfy the condition, $\theta_{e}<\theta_{p}[\mathrm{~h}]$,

$Q_{d c}$ - cooling energy produced by dry-cooler $[\mathrm{kWh} / \mathrm{m}]$,

$E_{d c}-$ cost of cooling energy from dry-cooler $[\mathrm{zt} / \mathrm{m}]$,

$Q_{a g r}-$ cooling energy produced by chiller $[\mathrm{kWh} / \mathrm{m}]$,

$t_{\text {agr }} \quad$ - operation time for chiller $[\mathrm{h} / \mathrm{m}]$,

$t_{\text {dagr }}$ - operation time for chiller $[\mathrm{d} / \mathrm{m}]$,

$E_{a g r}-$ cost of cooling energy from chiller $[\mathrm{z} / \mathrm{m}]$,

$\eta_{\text {agr }}$ - EER for chiller, 3,5.

\section{Introduction}

The issue of cold accumulation, relating to air conditioning systems, comprises both, preparation and storage as well. The installation of cold accumulation makes easy way to reduce the cost of cold production energy by using dualrate electricity charges. In addition, the cold accumulation systems allow to use devices with lower power demand and improve the reliability of the cooling system. Cooling energy can be stored in the form of sensible and latent. In the case of a sensible energy storage (SES) we deal with an increase of material temperature used as a accumulator of heat or cold, but in the case of latent heat storage (LHS) phase change material are used (usually between the solid and liquid). The air-conditioning system uses two main types of cold storage systems. These include: tank with ice water and cooling energy storage in materials PCM (phase change material) [3].

\section{Use cold water as a refrigerant}

Water is well suited for storage both heat and cold, due to high specific heat $(4.19 \mathrm{~kJ} / \mathrm{kgK})$. In practice, its mixture are common as a substances that reduce the freezing point. It is mostly ethylene glycol and propylene glycol as well. Cooling capacity of ice water tanks depend on the amount of stored water and the temperature difference $(\Delta t)$ between supply and return water. The temperature difference has a strong influence on the size of the accumulation reservoir. The values of the temperature difference of supply and return water flow through the accumulator are placed on level 7-9 K. In the case of an increase of this diffe- 
rence to the value of $11-13 \mathrm{~K}$ the volume of the reservoir will be reduced as close as to $50 \%$. The minimum value of $\Delta t$ at which the storage system is a costeffective is assumed as $5 \mathrm{~K}$. Chilled water accumulators can be made ground, partially buried or underground. They can also be integrated into the structure of the building. Ground storage tanks are often made of steel, underground as concrete bunkers [2]. Because of the simplicity of operation, reliability, efficiency and low investing cost the cold accumulation system are more and more common. Water has a melting heat of $335 \mathrm{~kJ} / \mathrm{kg}$, the high specific heat of $4.2 \mathrm{~kJ} / \mathrm{kgK}$, high density $1000 \mathrm{~kg} / \mathrm{m}^{3}$, the material is safe and has a melting point at a level suitable for use in conventional air conditioning systems.

The melting point is very stable and is $0^{\circ} \mathrm{C}$ at sea level. Under certain conditions, a slight supercooling of water close to 1 to $3 \mathrm{~K}$ is observed. After reaching the maximum supercooling point of water and freezing, it returns rapidly to $0^{\circ} \mathrm{C}[1]$.

The density of water is slightly reduced at temperatures below $4^{\circ} \mathrm{C}$ while the volume increased by $9 \%$ during freezing. This feature is used as an indicator of the formation of ice crystals in cold production systems in the form of frozen ice crystals. If frozen ice floats on the surface of the water volume remains constant until all of the water freeze or melt.

Below the freezing point of water ice slightly increases its density, but it does not matter accumulation cooling system because the majority of systems work close to of the phase changes of water.Scheme of capsules ice formation during charging and discharging process is shown in fig. 1.
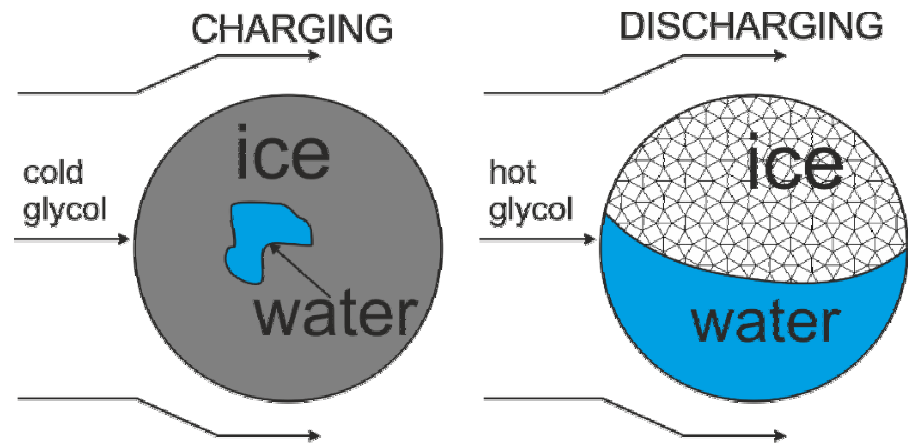

Fig. 1. Creation schema of ice during charging and discharging process

Rys. 1. Schemat powstawania lodu podczas procesu ładowania i rozładowywania

For ice capsules charging temperature decreases during freezing of water due to growth of the ice layer through which heat is conducted.

Water has become a dominant factor in the energy storage in air conditioning systems. However, some processes require medium temperature in the range that exceeds the capabilities of water systems. Therefore directed 
towards other substances that despite of freezing temperature above $0^{\circ} \mathrm{C}$ can produce refrigerant at satisfy temperature during the discharge process.

\section{Daily and seasonal cold accumulation}

The main task of the daily accumulation of cold is heat storage using a chiller, which charges the accumulator during night hours when the price of electricity is lower, which translates into lower operating costs (fig. 2).

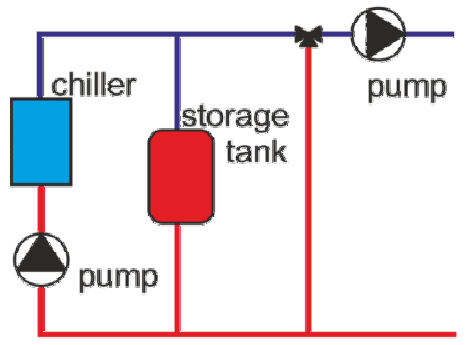

Fig. 2. Schema of daily cold accumulation

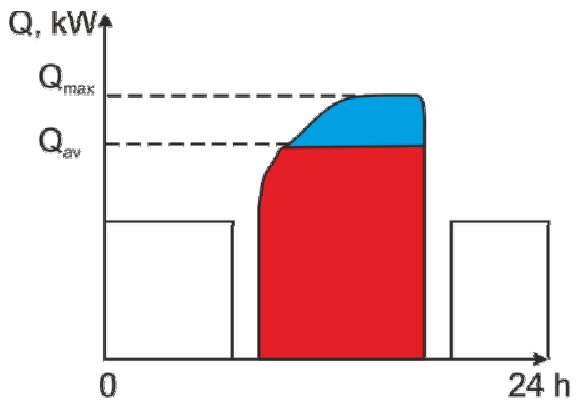

Rys. 2. Schemat systemu akumulacji dziennej

This process helps to save money not only on energy consumption but also on the costs related to purchasing a chiller that is selected on the maximum power of cold demand for unfavorable hour in whole year. The result - that most of the time during the summer season device unit seems to be oversized. But when the chiller is selected for average hour and cooling demand it will act as a complement to the maximum rise of possibility to choose a smaller and cheaper one. Seasonal cold accumulation is accumulation of cold in the container field or another. The cold production using the chiller or device for cooling water via the natural cooling capacity of air as dry-cooler. The tank must have a low $U$ coefficient to minimize losses of cold to the ambient air (fig. 3).
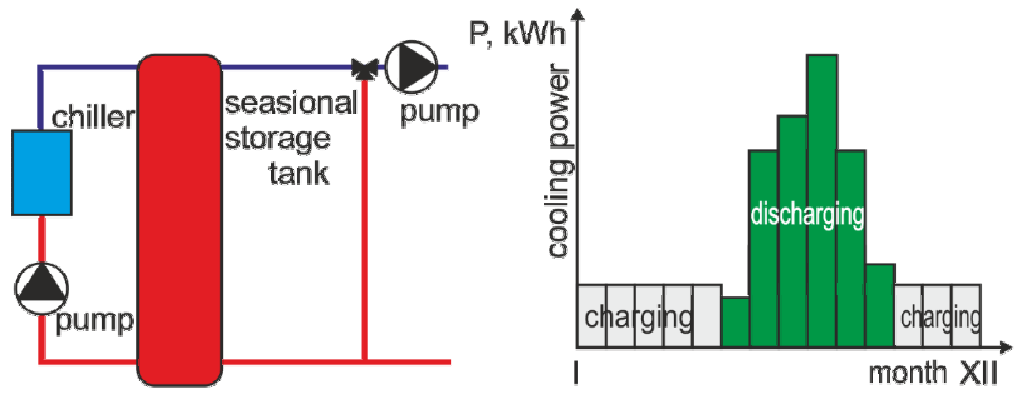

Fig. 3. Schema of seasonal cold accumulation

Rys. 3. Schemat układu akumulacji sezonowej 
This process is extremely beneficial because of the medium is lead to desired temperature at ambient one at low electricity demand and, in addition, this process takes place at night, when energy is cheaper. Dry-cooler can provide, depending on the weather about $60 \%$ of the total cooling demand in a year. The rest $40 \%$ is provided by the chiller.

\section{Calculation of cold storage volume}

The Inn type building was taken to calculation of monthly demand for cold presented in tab. 1.

Table 1. Cold demand for analyzed building

Tabela 1. Zapotrzebowanie na chłód dla analizowanego budynku

\begin{tabular}{|c|c|c|c|}
\hline Month & $\begin{array}{c}\text { Cold demand } \boldsymbol{Q}_{\text {cnd }} \\
{[\mathbf{k W h} / \mathbf{m}-\mathbf{t h}]}\end{array}$ & $\begin{array}{c}\text { Hours in month } \boldsymbol{t}_{\boldsymbol{M}} \\
{[\mathbf{h}]}\end{array}$ & $\begin{array}{c}\text { Time of building cooling } \boldsymbol{t}_{\boldsymbol{C}} \\
{[\mathbf{h}]}\end{array}$ \\
\hline 1 & 0,00 & 744 & 0 \\
\hline 2 & 0,00 & 696 & 0 \\
\hline 3 & 0,00 & 744 & 3 \\
\hline 4 & 25,89 & 720 & 30 \\
\hline 5 & 355,94 & 744 & 97 \\
\hline 6 & 1191,35 & 720 & 85 \\
\hline 7 & 973,37 & 744 & 111 \\
\hline 8 & 1321,64 & 744 & 30 \\
\hline 9 & 333,90 & 720 & 0 \\
\hline 10 & 0,00 & 744 & 0 \\
\hline 11 & 0,00 & 720 & $\mathbf{3 5 6}$ \\
\hline 12 & 0,00 & $\mathbf{7 4 4}$ & $\mathbf{8 7 8 4}$ \\
\hline $\boldsymbol{\Sigma}$ & $\mathbf{4 2 0 2 , 1 0}$ & & \\
\hline
\end{tabular}

The energy demand for cooling was calculated based on the method of preparation of energy performance certificates [5]. Seasonal accumulation of cooling will take place in the field reinforced concrete tank. The accumulation tank is filled with water. Refrigeration system operating time is set to $11 \mathrm{~h} /$ day from 8 to 19 in the summer period. The total cooling demand in time for the summer cooling was obtain as $E K=0.8 \mathrm{kWh} /\left(\mathrm{m}^{2}\right.$ year $)$. Discharging of cold accumulator takes place in the months of April, May, June, July, August, September, between the hours of 8 to 19 (highest cooling demand).

Storage tank charging will occur during the months of October, November, December, January, February, March, 8 hours a day (from 23 to 7). Overall cold demand of building in cooling season is placed on level $Q_{c, n d}=4202,10 \mathrm{kWh} / \mathrm{a}$. To serve the seasonal demand for cooling, ground cooling tank is loaded over 183 days, eight hours per day, which gives 1464 hours of charging during the year what give: $Q_{C, n d}=4202.10 \mathrm{kWh} / 1464=2,87 \mathrm{~kW}$ - power, which should be 
provided within hours of charging. The water was selected as accumulation material (phase change temperature $=293 \mathrm{~K}$ ). As the coolant (secondary refrigerant) a glycol-water mixture was selected.

Table 2. Characteristic parameters for cold accumulator - part 1

Tabela 2. Parametry charakterystyczne dla akumulatora chłodu - część 1.

\begin{tabular}{|c|r|r|r|r|r|r|r|r|}
\hline Month & $\begin{array}{c}\boldsymbol{\Theta}_{z \boldsymbol{p}} \\
{\left[{ }^{\mathbf{0}} \mathbf{C}\right]}\end{array}$ & $\begin{array}{c}\boldsymbol{\Theta}_{\boldsymbol{e}} \\
{\left[{ }^{\mathbf{0}} \mathbf{C}\right]}\end{array}$ & $\begin{array}{c}\boldsymbol{Q}_{\boldsymbol{c n , d}} \\
{[\mathbf{k W h} / \mathbf{m}]}\end{array}$ & $\begin{array}{c}\boldsymbol{Q}_{t r} \\
{[\mathbf{k W h} / \mathbf{m}]}\end{array}$ & $\begin{array}{c}\boldsymbol{t}_{\boldsymbol{C}} \\
{[\mathbf{h}]}\end{array}$ & $\begin{array}{c}\boldsymbol{Q}_{X} \\
{[\mathbf{k W h} / \mathbf{m}]}\end{array}$ & $\begin{array}{c}\boldsymbol{Q}_{\boldsymbol{k}} \\
{[\mathbf{k W h} / \mathbf{m}]}\end{array}$ & $\begin{array}{c}\mathbf{\Sigma} \boldsymbol{Q}_{\boldsymbol{k}} \\
{[\mathbf{k W h} / \mathbf{m}]}\end{array}$ \\
\hline 1 & 9,8 & 7,4 & 0,00 & 81,05 & 0 & 156,56 & $-1101,05$ & $-1257,61$ \\
\hline 2 & 7,7 & 6,9 & 0,00 & 31,68 & 0 & 156,56 & $-501,68$ & $-658,24$ \\
\hline 3 & 6,7 & 7,2 & 0,00 & $-36,42$ & 0 & 156,56 & $-258,58$ & $-415,14$ \\
\hline 4 & $\mathbf{6 , 0}$ & 8,2 & 25,89 & $-122,79$ & 3 & 156,56 & 93,68 & $-62,88$ \\
\hline 5 & 5,9 & 9,5 & 355,94 & $-186,88$ & 30 & 0,00 & 542,82 & 542,82 \\
\hline 6 & 6,8 & 10,9 & 1191,35 & $-176,13$ & 97 & 0,00 & 1367,48 & 1367,48 \\
\hline 7 & 9,0 & 12,2 & 973,37 & $-148,74$ & 85 & 0,00 & 1122,11 & 1122,11 \\
\hline 8 & 10,8 & 13,0 & 1321,64 & $-88,17$ & 111 & 0,00 & 1409,81 & 1409,81 \\
\hline 9 & 13,1 & 13,2 & 333,90 & $-26,60$ & 30 & 0,00 & 360,50 & 360,50 \\
\hline 10 & 13,6 & 12,4 & 0,00 & 25,04 & 0 & 0,00 & $-25,04$ & $-25,04$ \\
\hline 11 & 13,6 & 10,5 & 0,00 & 81,10 & 0 & 156,56 & $-911,10$ & $-1067,66$ \\
\hline $\mathbf{1 2}$ & 11,9 & 7,1 & 0,00 & 179,60 & 0 & 156,56 & $-1159,60$ & $-1316,16$ \\
\hline
\end{tabular}

Table 3. Characteristic parameters for cold accumulator - part 2

Tabela 3. Parametry charakterystyczne dla akumulatora chłodu - część 2.

\begin{tabular}{|c|c|c|c|c|c|c|c|c|c|}
\hline $\begin{array}{c}\boldsymbol{\Theta}_{z k} \\
{\left[{ }^{\circ} \mathbf{C}\right]}\end{array}$ & $\begin{array}{c}\boldsymbol{\Theta}_{s r} \\
{\left[{ }^{\circ} \mathbf{C}\right]}\end{array}$ & $\begin{array}{c}\boldsymbol{\Theta}_{p} \\
{\left[{ }^{\circ} \mathbf{C}\right]}\end{array}$ & $\begin{array}{c}\boldsymbol{\Theta}_{p^{-}} \boldsymbol{\Theta}_{e} \\
{\left[{ }^{0} \mathbf{C}\right]}\end{array}$ & $\begin{array}{c}t_{m p} \\
{[\mathbf{h} / \mathbf{m}]}\end{array}$ & $\underset{[\mathbf{k W h} / \mathbf{m}]}{\boldsymbol{Q}_{d c}}$ & $\begin{array}{c}E_{d c} \\
{[\mathrm{kWh} / \mathbf{m}]}\end{array}$ & $\underset{[\mathbf{k W h} / \mathbf{m}]}{Q_{a g r}}$ & $\begin{array}{c}t_{a g r} \\
{[\mathbf{h} / \mathbf{m}]}\end{array}$ & $\begin{array}{c}\boldsymbol{E}_{a g r} \\
{[\mathbf{z} \mathbf{t} / \mathbf{m}]}\end{array}$ \\
\hline 7,7 & 8,7 & 0,7 & $-6,7$ & 204 & 1020,0 & 64,3 & 192,12 & 42,88 & 24,70 \\
\hline 6,7 & 7,2 & $-0,3$ & $-7,2$ & 94 & 470,0 & 29,6 & 192,12 & 42,88 & 24,70 \\
\hline 6,0 & 6,3 & $-1,0$ & $-8,2$ & 59 & 295,0 & 18,6 & 192,12 & 42,88 & 24,70 \\
\hline 5,9 & 5,9 & $-1,1$ & $-9,3$ & 11 & 55,0 & 3,5 & 192,12 & 42,88 & 24,70 \\
\hline 6,8 & 6,3 & - & - & - & - & - & - & - & - \\
\hline 9,0 & 7,9 & - & - & - & - & - & - & - & - \\
\hline 10,8 & 9,9 & - & - & - & - & - & - & - & - \\
\hline 13,1 & 11,9 & - & - & - & - & - & - & - & - \\
\hline 13,6 & 13,4 & - & - & - & - & - & - & - & - \\
\hline 13,6 & 13,6 & - & - & - & - & - & - & - & - \\
\hline 11,9 & 12,7 & 4,9 & $-5,6$ & 166 & 830,0 & 52,3 & 192,12 & 42,88 & 24,70 \\
\hline 9,8 & 10,8 & 2,8 & $-4,3$ & 196 & 980,0 & 61,7 & 192,12 & 42,88 & 24,70 \\
\hline & & $\mathbf{7 3 0 , 0}$ & 3650,0 & 230,0 & 1152,72 & 257,30 & 32,16 & 148,21 & \\
\hline
\end{tabular}

The calculations The cold loses from the tank to the environment $Q_{t r}$ has been taken into the account determined on the PN-EN ISO 13790 [4]. The calculations are summarized in tab. 2 and 3. The tables show that the cool 
accumulator releases the most energy in the summer months, ie. June, July, August. In May and September temperatures are much lower because the accumulator in these months is not used.

Table 4. Operating time for dry-cooler

Tabela 4. Czas pracy systemu dry-coolera

\begin{tabular}{|c|c|c|}
\hline Month & $\begin{array}{c}\text { Oparating temp. of dry-cooler } \\
\boldsymbol{\Theta}_{\boldsymbol{p}} \\
{\left[{ }^{\mathbf{}} \mathbf{C}\right]}\end{array}$ & $\begin{array}{c}\text { Time of dry-cooler operation } \\
\boldsymbol{t}_{\boldsymbol{m} \boldsymbol{p}} \\
{[\mathbf{h} / \mathbf{m o n t h}]}\end{array}$ \\
\hline 1 & 0,7 & 204 \\
\hline 2 & $-0,3$ & 94 \\
\hline 3 & $-1,0$ & 59 \\
\hline 4 & $-1,1$ & 11 \\
\hline 11 & 4,9 & 166 \\
\hline 12 & 2,8 & 196 \\
\hline & $\boldsymbol{\Sigma}$ & $\mathbf{3 6 2}$ \\
\hline
\end{tabular}

To determine the number of hours in cooling season during which the outdoor temperature is lower than the return glycol temperature into the tank the data from meteorological stations in Rzeszów Jasionka was used.

The energy provided by a dry-cooler in the each months (tab. 4), when the outdoor temperature is lower than the temperature in the cooled room (simplified) $\theta_{e}<\theta_{p}$ and energy provided by the chiller was counted according to the following scheme.

1. Dry-cooler

$$
Q_{d c}=t_{m p} \cdot N_{u}[\mathrm{kWh}]
$$

Assumed power output of the device is $N_{u}=5 \mathrm{~kW}$. To sum up months of work of dry-cooler the total power of the device in the season is obtained.

$$
\Sigma Q_{d c}=Q_{d c, I}+Q_{d c, I I}+Q_{d c, I I I}+Q_{d c, I V}+Q_{d c, X I}+Q_{d c, X I I}[\mathrm{kWh}]
$$

Then, cold produced by dry-cooler only: $\Sigma Q_{d c}=1020,0+470,0+295,0+$ $+55,0+830,0+980,0=3650,0 \mathrm{kWh}$.

2. Chiller

$$
Q_{a g r}=\Sigma Q_{k x, u}-\Sigma Q_{d c}=4802,72-3650,0=1152,72 \mathrm{kWh}
$$

Working time of the chiller $T_{a g r}$ is:

$$
T_{a g r}=\frac{Q_{a g r}}{N_{u, a g r} \cdot n}
$$


The number of month taken in accumulation process $n=6$ and power of chiller

$$
N_{u, a g r}=4,5 \mathrm{~kW} \text {. Then, } T_{a g r}=\frac{1152,72}{4,5 \cdot 6}=42,88 \mathrm{~h} .
$$

Comparison between cold production by chiller and dry-cooler was shown in fig. 4. The below chart shows the power that is provided by dry-cooler and chiller. Most productive months for dry-cooler operation are November, December and January. While the chiller is running 5 or 4 days in each month to complete the charging of cooling accumulator, which could provide a dry-cooler because of too high ambient temperatures and monthly downtime for service and maintenance.

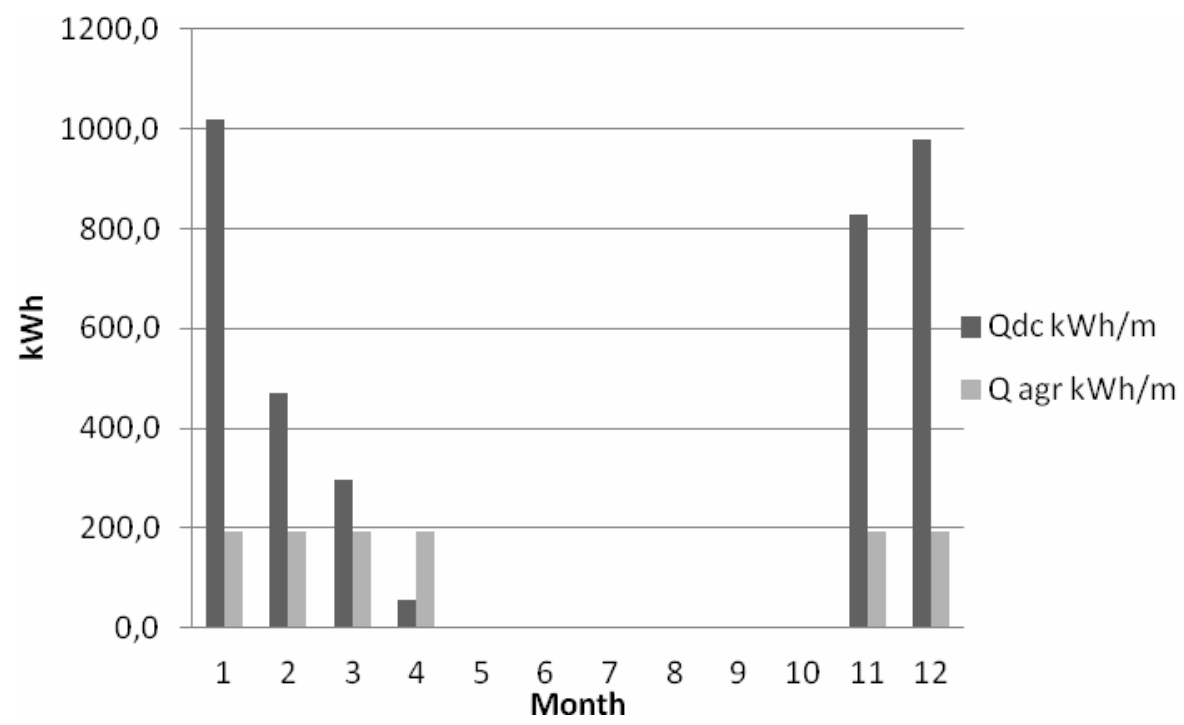

Fig. 4. Cold production provided by chiller and dry-cooler

Rys. 4. Przewidywana produkcja chłodu przez chiller i dry-cooler

Figure 5 presents the chiller operating costs and dry-cooler along with circulation pumps and compressor for the analyzed system. The total cost of exploitation of these devices is placed on level $E=E_{d c}+E_{a g r}=230,0+148,21=$ $=378,2 \mathrm{zt}$.

The cost of energy for the chiller only:

$$
E_{c}=\frac{Q_{k x}}{\eta_{a g r}} \cdot N_{u, a g r}=\frac{4802,72}{3,5} \cdot 0,45=617,5 \mathrm{zł}
$$

Saving energy between the chiller system without cooling accumulator, but with dry-cooler is $239,3 \mathrm{zt}$ per year which allows for savings of $39 \%$. 


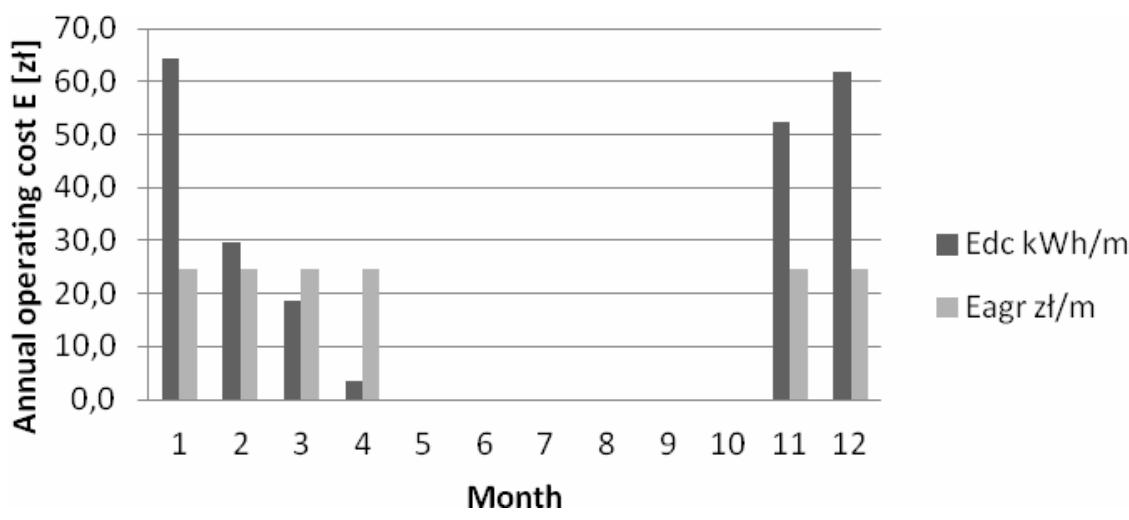

Fig. 5. Annual operating cost for dry-cooler and chiller including pumps and compressor Rys. 5. Roczne koszty pracy dla układu chillera i dry-coolera łącznie z pompami i sprężarką

Sizing seasonal cold accumulator after taking into account the heat loss through the tank permeation barriers:

$$
V=\frac{3600 \cdot \Sigma Q_{k x, u}}{c_{m} \cdot \rho_{m} \cdot \Delta T} \mathrm{~m}^{3}
$$

Assuming:

$$
\begin{aligned}
& \Delta T=7^{\circ} \mathrm{C}, \\
& \rho_{m}=0,67 \cdot 999,7+0,33 \cdot 1018=1005,74 \mathrm{~kg} / \mathrm{m}^{3} \text { (mixture water and glycol), } \\
& \Sigma Q_{k x, u}=4802,72 \mathrm{kWh}, \\
& C_{m}=3,84 \frac{\mathrm{kJ}}{\mathrm{kgK}} .
\end{aligned}
$$

The volume is $V=\frac{3600 \cdot 4802,72}{3,84 \cdot 1005,74 \cdot 7}=639,55 \mathrm{~m}^{3}$.

\section{Conclusions}

Design seasonal cold accumulator allows to conclude that this solution has a number of economic and ecological advantages. Due to the seasonal tank design the saves on chiller, which under normal circumstances would have been selected for the highest hourly energy demand, which means that the device should be several times larger than the device that was used in the project. By 
selecting a small chiller the environment from hazardous refrigerants is protected, which are chlorofluorocarbons, specifically in the case of refrigerant called R - 410A. Another huge advantage of the project is to provide the majority of the demand for cooling by dry-cooler, thanks to its simple design makes use of Polish temperate climate where winter occurs. It allows to charge cold accumulator without additional costs for electricity. With its rechargeable accumulator with a dry-cooler and chiller a lot of savings during operation period of the system is achieved at the level of $40 \%$. It is without a doubt a very good result.

The disadvantage is that the size of the cold accumulator, and thus the cost of excavation and tank with a low coefficient of heat transfer. All of above make this investment expensive with the 15 years of operation of the system return. This fact force to seek other cold storage solutions or substance which are able to give higher specific heat ratio. This can be done for example by the use of phase change materials, PCM, with a heat capacity is in the range $18,0 \mathrm{~kJ} / \mathrm{kgK}$, which in comparison with the glycol-water mixture used in the project, 3,84 $\mathrm{kJ} / \mathrm{kgK}$ makes possible to reduce accumulation container more than 4.5 times. That container can be moved inside the building which result in lower costs for excavation works and the cost of the tank itself.

\section{Literature}

[1] Hasnain S.M.: Review on sustainable thermal energy storage technologies. Part I: Heat storage materials and techniques. Energy Research Institute, King Abdulaziz City for Science and Technology. P.O. Box 6086, Riyadh 11442, Saudi Arabia.

[2] Lewandowski W.M.: Proekologiczne źródła energii odnawialnej. WNT, Warszawa 2001.

[3] Mehling H., Cabeza L.F.: Heat and cold storage with PCM. Springer 2008.

[4] PN-EN ISO 13790 November 2008: Energetyczne właściwości użytkowe budynków Obliczanie zużycia energii na potrzeby ogrzewania i chłodzenia.

[5] Rozporządzenie Ministra Infrastruktury z dnia 6 listopada 2008 r. w sprawie metodologii obliczania charakterystyki energetycznej budynku i lokalu mieszkalnego lub części budynku stanowiącej samodzielną całość techniczno-użytkową oraz sposobu sporządzania i wzorów świadectw ich charakterystyki energetycznej.

\section{SEZONOWY AKUMULATOR CHLODU Z FREE-COOLINGIEM DLA SYSTEMU KLIMATYZACJI}

Streszczenie

Jednym ze sposobów zmniejszenia zużycia tradycyjnych źródeł energii jest użycie sezonowej akumulacji chłodu, która wykorzystuje położenie geograficzne oraz pozwala w sezonie zimowym (od listopada do marca) zgromadzić energię chłodniczą dzięki niskim wartościom temperatury. Umożliwia to pozyskanie oszczędności znacznych ilości energii do chłodzenia w sezonie letnim i zmniejszenia oddziaływania urządzenia chłodniczego na środowisko, które to w więk- 
szości przypadków jest szkodliwe. W pracy przedstawiono metodę określania wielkości energii przeznaczonej do chłodzenia przez cały rok, pochodzącą $\mathrm{z}$ agregatu chłodniczego i produkcji chłodu w urządzeniu w postaci dry-coolera w systemie akumulacji jawnej. Przedstawiono przybliżone koszty eksploatacji urządzeń, w tym czas pracy poszczególnych systemów, tj. chillera i dry-coolera. Zaproponowano konstrukcję sezonowego akumulatora chłodu, której zastosowanie ma wiele zalet ekonomicznych i ekologicznych. Ze względu na akumulację chłodu w sezonie możliwe jest uzyskanie sporych oszczędności na pracy agregatu chłodniczego, który w normalnych warunkach zostałby wybrany dla największego godzinowego zapotrzebowania na energię chłodniczą. Oznacza to, że urządzenie musiałoby mieć kilka razy większą wydajność w porównaniu z urządzeniem przyjętym w projekcie. Przez wybór chillera małej mocy projekt z założenia ma na celu ochronę środowiska naturalnego przed niebezpiecznymi czynnikami chłodniczymi w postaci tzw. „freonów”, w większości stosowanych na skalę przemysłową w tego typu urządzeniach.

Słowa kluczowe: free-cooling, akumulator chłodu, klimatyzacja, magazynowanie sezonowe

Przestano do redakcji: $21.10 .2014 r$.

Przyjęto do druku: 02.12.2014 r.

DOI:10.7862/rb.2014.135 
